\title{
SCN11A gene deletion causes sensorineural hearing loss by impairing the ribbon synapses and auditory nerves
}

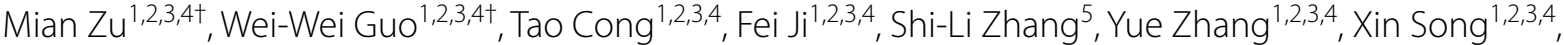 \\ Wei Sun ${ }^{6}$, David Z. Z. He ${ }^{7}$, Wei-Guo Shi ${ }^{*}$ and Shi-Ming Yang ${ }^{1,2,3,4^{*}}$ (I)
}

\begin{abstract}
Background: The SCN11A gene, encoded Nav1.9 TTX resistant sodium channels, is a main effector in peripheral inflammation related pain in nociceptive neurons. The role of SCN11A gene in the auditory system has not been well characterized. We therefore examined the expression of SCN11A in the murine cochlea, the morphological and physiological features of Nav1.9 knockout (KO) ICR mice.

Results: Nav1.9 expression was found in the primary afferent endings beneath the inner hair cells (IHCS). The relative quantitative expression of Nav1.9 mRNA in modiolus of wild-type (WT) mice remains unchanged from P0 to P60. The number of presynaptic CtBP2 puncta in Nav1.9 KO mice was significantly lower than WT. In addition, the number of SGNs in Nav1.9 KO mice was also less than WT in the basal turn, but not in the apical and middle turns. There was no lesion in the somas and stereocilia of hair cells in Nav1.9 KO mice. Furthermore, Nav1.9 KO mice showed higher and progressive elevated ABR threshold at $16 \mathrm{kHz}$, and a significant increase in CAP thresholds.
\end{abstract}

Conclusions: These data suggest a role of Nav1.9 in regulating the function of ribbon synapses and the auditory nerves. The impairment induced by Nav1.9 gene deletion mimics the characters of cochlear synaptopathy.

Keywords: TTX resistant sodium channels, Expression, Nav1.9 knockout, Ribbon synapse, SGN, Progressive hearing loss, Synaptopathy

\section{Background}

The Nav1.9 sodium channel, encoded by SCN11A gene, was first identified in 1996 as an unusual voltage-gated sodium channel called SNS [1]. The Nav1.9 channel is well known for its presence in small-diameter nociceptive neurons dorsal root ganglion (DRG) $[2,3]$, trigeminal ganglia $[4,5]$ and myenteric intrinsic primary afferent

\footnotetext{
*Correspondence: shiwg1988@126.com; yangsm301@263.net ${ }^{\dagger}$ Mian Zu and Wei-Wei Guo contributed equally to this work ${ }^{1}$ College of Otolaryngology Head and Neck Surgery, Chinese PLA General Hospital, Beijing, China

${ }^{8}$ State Key Laboratory of Toxicology and Medical Countermeasures, Beijing Institute of Pharmacology and Toxicology, Beijing, China Full list of author information is available at the end of the article
}

neurons [6]. Recent studies found that Nav1.9 channel also expressed in photoreceptors and Muller glia in the visual system [7]. Nav1.9 shares only 50\% identity with the other voltage-gated $\mathrm{Na}^{+}$channel isoforms, but it doesn't belong to a new Nav subfamily according to phylogeny [8]. Nav1.9 carries a serine (S) residue in the DI-SS2 pore region, rather than a tyrosine $(\mathrm{Y})$ or a phenylalanine $(\mathrm{F})$, which markedly reduces the affinity of the TTX-channel interaction by more than 200-fold [9].

Nav1.9 typically exhibits ultra-slow kinetics with an activation at around $-65 \mathrm{mV}$, lower than Nav1.1, a TTX sensitive sodium channel [10], the consolidation of which is important for the maturation of afferent fiber in the weeks after hearing onset. Unlike Nav1.1, Nav1.9

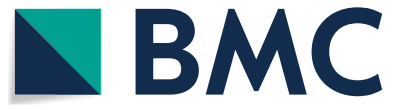

(c) The Author(s) 2021. This article is licensed under a Creative Commons Attribution 4.0 International License, which permits use, sharing, adaptation, distribution and reproduction in any medium or format, as long as you give appropriate credit to the original author(s) and the source, provide a link to the Creative Commons licence, and indicate if changes were made. The images or other third party material in this article are included in the article's Creative Commons licence, unless indicated otherwise in a credit line to the material. If material is not included in the article's Creative Commons licence and your intended use is not permitted by statutory regulation or exceeds the permitted use, you will need to obtain permission directly from the copyright holder. To view a copy of this licence, visit http://creativeco mmons.org/licenses/by/4.0/. The Creative Commons Public Domain Dedication waiver (http://creativecommons.org/publicdomain/ zero/1.0/) applies to the data made available in this article, unless otherwise stated in a credit line to the data. 
does not contribute so much to the amplitude of action potential, but facilitate excitation of small depolarization by amplifying receptor potentials. The 'ultra-slow' inactivation of Nav1.9 renders the persistence of the sodium current after activation, corresponding to a wide range of voltage to keep a persistently open channel close to the resting membrane potential [11]. The biophysical properties of Nav1.9 channels suggest their probable contribution to prolonging the response to a subthreshold stimulus and supporting repetitive firing [12].

Nav1.9 mediates tissue-damage in DRG with unmyelinated $\mathrm{C}$ fibers by transforming receptor potentials into action potentials. Nav1.9 KO mice shows less stimulation-induced calcitonin gene-related peptide (CGRP) release form skin, which implies that Nav1.9 has a role in modulating neurotransmitter release from afferent nerve endings [13]. Cochlea includes two types of auditory nerves. Type I afferents are myelinated innervating to IHCs, while Type II afferents are unmyelinated innervating outer hair cells (OHCs). Type II afferents may be the cochlearnociceptors, as highly enriched gene ontology (GO) terms in type II neurons (Prph+, Th+), were associated with "response to stress" and "pain" by single cell RNA-seq sequencing [14].

Multiple TTX-sensitive $\mathrm{Na}^{+}$currents, including a subthreshold persistent $\mathrm{Na}^{+}$current $\left(\mathrm{I}_{\mathrm{NaP}}\right)$, a resurgent $\mathrm{Na}^{+}$ current $\left(\mathrm{I}_{\mathrm{NaR}}\right)$ and fast inward sodium currents, could be recorded in cultured SGNs after the onset of hearing, while the function of Nav1.9 in auditory sensory system remains enigmatic $[15,16]$. The gene expression microarray shows that, SCN11a shares a similar pattern with atonal homolog 1a (Atoh1) during hair cell differentiation, which is a well-known factor during inner ear development [17]. The relative expression level of SCN11a in cochlea is 1.7 compared with that of Atoh1 as 5.2 [18]. Moreover, Nav1.9 protein is expressed in cartwheel cells (CWCs) in the dorsal cochlear nucleus (DCN). And Nav1.9 is proved to contribute to respond with compound action potential (CAP) containing single action potentials (SAPs) superimposed on a slow depolarization [19].
In this paper we studied the expression and function Nav1.9 in the cochlea of mice. We found abnormal ABRs and CAPs, as well as decreased presynaptic CtBP2 puncta and SGN in Nav1.9 KO mice, suggesting impairment of the auditory signal transmission. Nav1.9 may contribute to auditory neurotransmission, sharing a similar protein expression pattern in nociceptive neurons of DRG as an effector of peripheral pain hypersensitivity.

\section{Methods}

All animal procedures were carried out in accordance with the Policy on Human Care and Use of Laboratory Animals at PLA General Hospital and approved by the Institutional Animal Care and Use Committee (process no. 2018-X14-84).

\section{Construction of Nav1.9 $9^{-/-}$mice using CRISPR/Cas9}

Nav1.9 $9^{-/-}$ICR mice were obtained from CasGene Biotech. Co., Ltd. The specific single-guide RNAs (gRNAs) were designed and synthesized (gRNA1: ccctgtagtcgtttgaaggttag; gRNA2: cccattccgcgaccagctgtggc). To generate Nav1.9 knockout mice, gRNAs targeting a section of the SCN11A gene encoding sequence beside the PAM sequence, and Cas9 nucleases could introduce a double-strand break (DSB) (Fig. 1a). The all-in-one plasmid expressing Cas9 and gRNAs was microinjected into fertilized eggs under micromanipulation. About 3 weeks after the injection of eggs to a pseudopregnant female, the founder mice were obtained. The homologous genetic deletion was identified by PCR amplification (forward primer: 5'-GACACTCTGGCGGT GCC TTCC-3'; KO specific reverse primer: 5'-TTGCTCCCA CCTTACCAATACAGACTC-3'; WT specific reverse primer: 5'-CGACATTCCTCCGAGACCTGTTAGA-3') and DNA sequencing analysis. The off-target effect and germline transmission to the offspring were then determined. Heterozygous males and females were mated to produce wildtype (WT), heterozygous and homozygous offspring. Mice were maintained in a humidity and temperature-controlled IVC animal experiment system with $12 \mathrm{~h}$ light/dark cycle.

\footnotetext{
(See figure on next page.)

Fig. 1 CRISPR/Cas 9-mediated generation of a Nav1.9-/- mouse model. a A representative illustration of the CRISPR/Cas9 targeting strategy for generating Nav1.9 knockout (KO) mice. The Cas9 mRNA and two single guide RNAs targeting a region from SCN11A exon 3 to 5, were microinjected into mouse zygotes. $\mathbf{b}$ Schematic diagram of primer pair design for PCR genotyping, a representative PCR genotyping result for

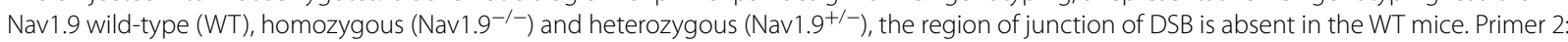
primer pairs containing forward primer and $\mathrm{KO}$ specific reverse primer; Primer 1: primer pairs containing forward primer and WT specific reverse primer. c This successfully eliminated all of exon 3, 4 and 5, as confirmed by Sanger sequencing, induces reading frame shift and thus a premature translational- termination codon during the truncated protein expression. $\mathbf{d}$ The protein expression of Nav1.9 in the cochleas of Nav1.9-/- mice $(n=3)$ or WT mice $(n=4)$ was measured by western blot
} 


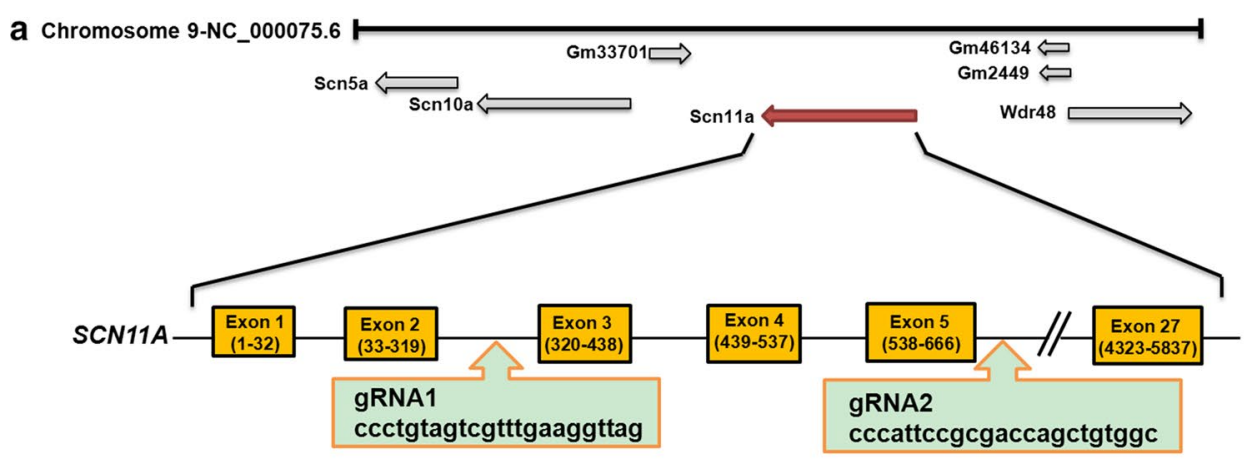

b

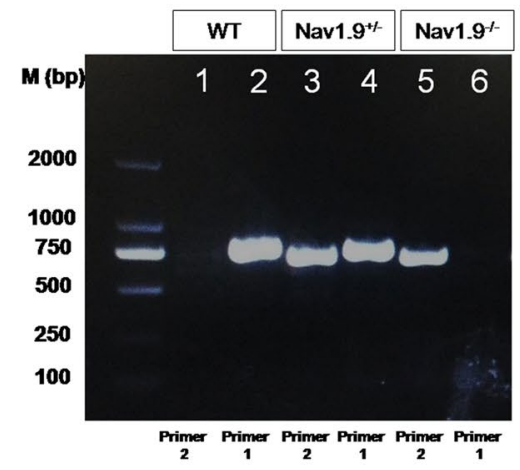

c
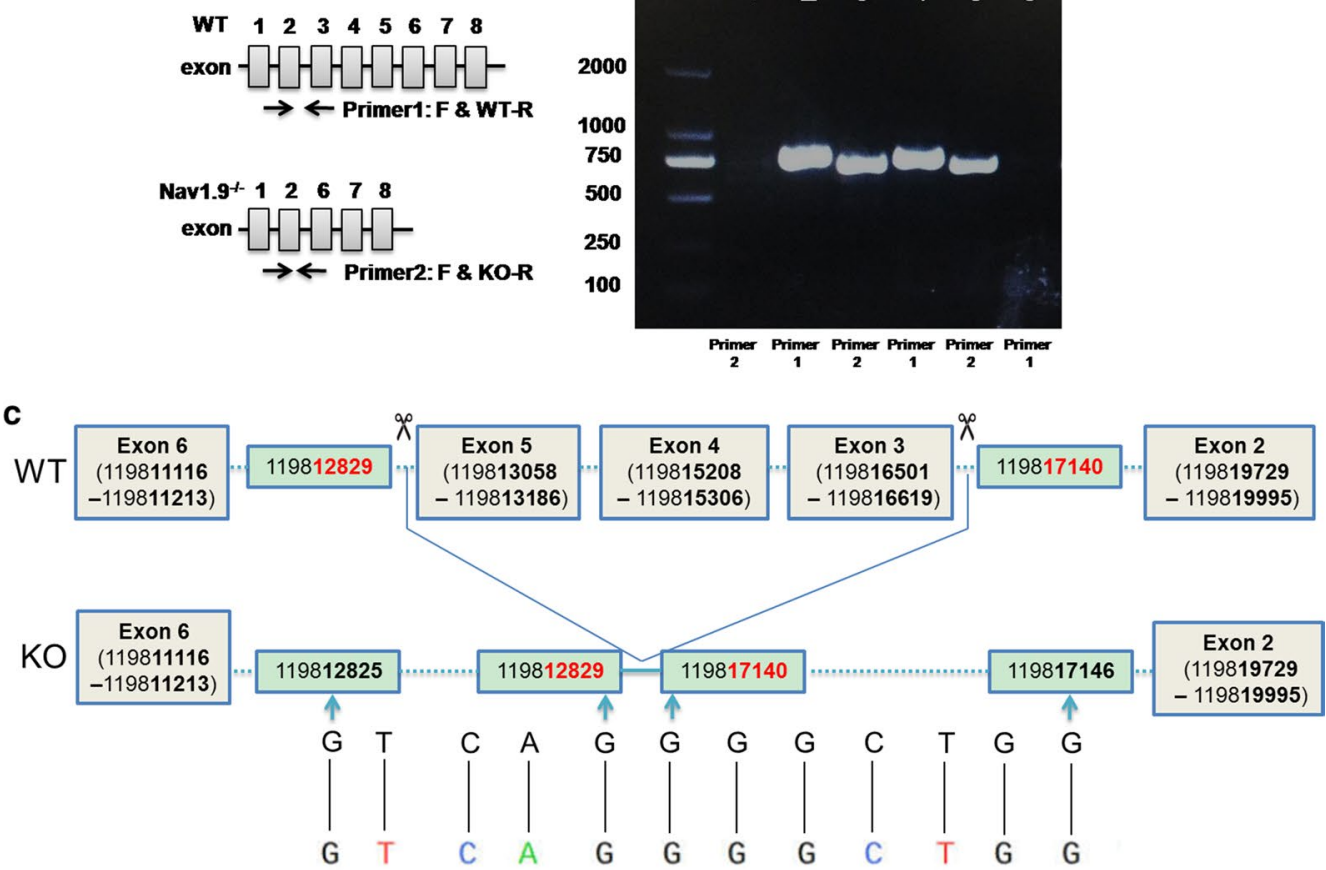

$-119815306)$

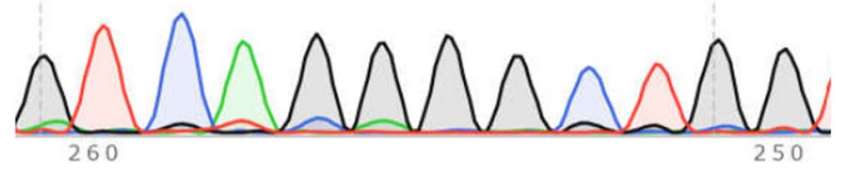

Truncated protein:
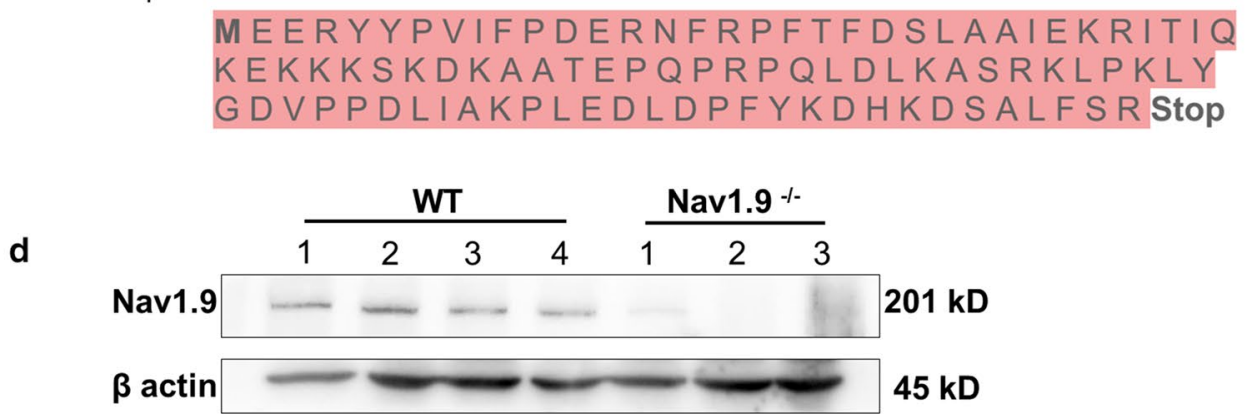


\section{Real-time quantitative PCR}

Real-time quantitative PCR (qPCR) was used to identify mRNA expression of Nav1.9 in cochlea of mice at different time points after birth (P0, P7, P14, P21, P28 and P60), with five mice in each group. Total RNA from modiolus was prepared by RNeasy Mini Kit (cat. 74104, QIAGEN) followed by purity determination and quantitation. cDNA was synthesized by random primer using the TransScript first-strand synthesis supermix for RTPCR (TransGen Biotech). qPCR with reaction volume of $20 \mu \mathrm{L}$ containing primers $(200 \mathrm{nM})$ and $1 \mu \mathrm{L}$ cDNA, was performed on $\mathrm{CFX}^{\mathrm{TM}}{ }^{\mathrm{TM}}$ Real-Time PCR Detection Systems (Bio-Rad Life Science). Specific primers for Nav1.9, Nav1.1 and GAPDH (housekeeping gene) were designed and synthesized (Table 1). The following run protocol for amplification was used: denaturation $\left(94{ }^{\circ} \mathrm{C}\right.$ for $\left.30 \mathrm{~s}\right)$, amplification and quantification by 45 cycles $\left(94{ }^{\circ} \mathrm{C}\right.$ for $5 \mathrm{~s}, 56.8{ }^{\circ} \mathrm{C}$ for $15 \mathrm{~s}, 72{ }^{\circ} \mathrm{C}$ for $10 \mathrm{~s}$ ), melting curve (65$95{ }^{\circ} \mathrm{C}$ with a heating rate of $0.1{ }^{\circ} \mathrm{C} / \mathrm{s}$ ). Negative controls with $\mathrm{Ct}$ values more than 38 or no visible amplification curve were tested in each run. The relative expression level was calculated by the $2^{-\Delta \Delta \mathrm{Ct}}$ method as previously described [20,21].

\section{Cochlea sectioning and scanning electron microscopy (SEM)}

After the anesthesia by an intraperitoneal injection of pentobarbital sodium $(50 \mathrm{mg} / \mathrm{kg})$, the $\mathrm{P} 60$-adult mice were sacrificed by decapitation. The cochleas were isolated and fixed in 4\% paraformaldehyde overnight, followed by decalcification in 10\% EDTA at room temperature for $24 \mathrm{~h}$. For cochlea immunostaining, the tissues were cryoprotected successively in 20\% and 30\% sucrose in PBS for $2 \mathrm{~h}$ and in Tissue Freezing Medium (OCT) at $4{ }^{\circ} \mathrm{C}$ until they sank. The cryoprotected tissues were sectioned at $10 \mu \mathrm{m}$ for immunostaining, while sections at $2 \mu \mathrm{m}$ were prepared for hematoxylin and eosin staining.

For the SEM, the cochlea was perfused and fixed with $2.5 \%$ glutaraldehyde. After decalcified in 10\% EDTA, cochleas were post-fixed with $1 \%$ osmium tetroxide,

Table 1 Primers for real-time RT-PCR analysis

\begin{tabular}{|c|c|c|}
\hline \multirow[t]{2}{*}{ Target } & \multicolumn{2}{|l|}{ Sequence $\left(5^{\prime}\right.$ to $\left.3^{\prime}\right)$} \\
\hline & Forward primer & Reverse primer \\
\hline Nav1.1 & TTCAGGGGCTATCGAGGC & $\begin{array}{l}\text { TGCTGAATAATGAGTGTACCA } \\
\text { AAAT }\end{array}$ \\
\hline Nav1.9 & $\begin{array}{l}\text { GAAAAAGTTAGGTGGCCA } \\
\text { AGACAT }\end{array}$ & GTTGGGCTGGCCTTCAGATT \\
\hline GAPDH & GGAATGCCTACCTTGCCCTG & ATGTCTTGGCCACCTAACTTTT \\
\hline
\end{tabular}

dehydrated and embedded on aluminum stubs, coated with gold particles.

\section{Immunohistochemistry and synaptic counts}

After washes with $0.1 \%$ Triton X-100 in PBS, sections on adhesion microscope slides were blocked with $10 \%$ normal goat serum (ZLI-9021, ZSGB-BIO) and incubated with rabbit anti-SCN11A polyclonal antibody (AT322395, 1:200, OriGene, Rockville, MD), guinea pig anti-Nav1.9 polyclonal antibody (AGP-030, 1:200, alomone labs, Israel), mouse anti-CtBP2 (612044, 1:100, BD Biosciences), in $10 \%$ goat serum diluted in $0.1 \mathrm{M}$ PBS at $4{ }^{\circ} \mathrm{C}$ overnight and then incubated with secondary antibodies containing anti-mouse Alexa Fluo ${ }^{\mathrm{TM}} 488$ (lot 1810918, 1:400, goat, Thermo Fisher), anti-rabbit Alexa Fluor $^{\text {TM }} 568$ (lot 1494753, 1:400, goat, Thermo Fisher), or anti-guinea pig Alexa Fluro ${ }^{\mathrm{TM}} 647$ (A-21450, 1:400, goat, Thermo Fisher). Cell nuclei were labeled by DAPI.

For pre-synaptic ribbons counts, all pieces of each basilar membrane for each mouse were imaged with converted locations into frequency by ImageJ Plugin according to Cochlear Frequency Mapping in Whole Mounts (MASSACHUSETTS EYE AND EAR). Confocal z stacks from 4.0 to $64.0 \mathrm{kHz}$ regions form each cochlea were taken using a LEICA DMi8 microscope equipped with $63 \times$ oil immersion lens. Five random fields at the region of 20-50\% [mouse standardized cochleogram according to Müller et al. [22] from the apex were chosen for pre-synaptic ribbons counting, corresponding to the frequency around $8-16 \mathrm{kHz}$. The $\mathrm{z}$ stacks with $10 \mu \mathrm{m}$ $(0.75 \mu \mathrm{m}$ step size) were set to ensure all the synaptic specializations were imaged. CtBP2 puncta in superimposed confocal z stacks was visualized and counted as presynaptic counts for each IHC. Each image usually contained 17-25 IHCs [23].

\section{Haematoxylin Eosin (H\&E) staining and SGN counting}

The sections were deparaffinized with xylene twice (10 min each), followed by re-hydration in 2 changes of absolute alcohol (5 min each), 95\% alcohol, 85\% alcohol, $75 \%$ alcohol (2 min each) and washed in distilled water briefly. Then the sections were stained in Harris hematoxylin solution and counterstained in eosin-phloxine solution. The sections were dehydrated through 95\% alcohol and absolute alcohol and cleared in xylene twice, 5 min for each time. Finally, the mounted sections were observed under a light microscope [24].

The established method of paraffin slide was used for auditory neuron count [25]. In 5 mid-modiolus slices per cochlea from paraffin-embedding tissue, with $2 \mu \mathrm{m}$ each on every 5th section, the perimeters of Rosenthal's Canal were surveyed and the mean cell number of 5 slices was regarded as neuron count for one mouse. The number of 
SGNs with soma diameter equal or greater than $13 \mu \mathrm{m}$ within the apex, middle and basal modiolus were chosen and counted manually with the assistant of Image J, respectively [26].

\section{Western blot analysis}

Four wildtype mice and 3 Nav1.9 knockout mice were included in WB assay. Protein lysate from bilateral cochlea samples for each mouse was prepared in RIPA lysis buffer with the adding of complete protease inhibitor by Tissue Grinding Pestles, followed by keeping in an ice bath for $10 \mathrm{~min}$. After centrifugation at 12,000 rpm for 10 min at $4{ }^{\circ} \mathrm{C}$, the supernatant mixed with loading buffer was denatured and loaded on a SDS-PAGE (12\%) gel. Proteins were transferred to PVDF membrane for $90 \mathrm{~min}$ in an ice bath. After blocking, the membrane was incubated in primary antibodies of anti-Nav1.9 and anti- $\beta$ actin with gentle agitation at $4{ }^{\circ} \mathrm{C}$ overnight, followed by HRP-conjugated secondary antibody incubation. Finally, the signal of HRP was detected using GE Healthcare's ECL detection reagent. Antibodies in this study were as follows: polyclonal rabbit anti-SCN11A polyclonal antibody (AT322395, 1:1000, OriGene), beta Actin mouse monoclonal antibody (TA811000, 1:1000, OriGene), anti-rabbit HRP-linked IgG (7074, 1:4000, Cell Signaling Technology), goat anti-mouse HRP-linked IgG $(\mathrm{H}+\mathrm{L})$ (LK2003, 1:4000, sungene biotech).

\section{Auditory brainstem response (ABR) and ECoch G recording} Mice were anesthetized using an intraperitoneal injection of pentobarbital sodium $(50 \mathrm{mg} / \mathrm{kg})$ and kept on a thermal insulation blanket. Click stimuli or pure tone stimuli from 2 to $16 \mathrm{kHz}$ were generated by Tucker Davis Technologies System (TDT) and delivered by a MF1 speaker (TDT) [27]. The intensity of the tone stimuli was calibrated using a sound level meter with 1/4-inch pressurefield microphone (B\&K). Response signals were recorded from the scalp vertex by needle electrodes, the postauricular region of the ipsilateral ear as reference, and the contralateral ear as ground. Auditory thresholds were determined as the lowest sound intensity with reproducible and recognizable waves by decreasing the sound intensity from 100 to $10 \mathrm{~dB}$ SPL in $5 \mathrm{~dB}$ steps. Mean \pm SD was plotted as a function of stimulating sound frequencies, or a function of months after birth at one frequency for each genotype [28].

For ECochG recordings, the left cochlea was exposed through a dorsolateral posterior-auricular surgical approach. Once the bulla had been opened by a cutting burr, the recording electrode was placed on the round window membrane with the aid of a micromanipulator. The reference and ground electrodes were placed in the muscle near the cochlea. When the CAP of the auditory nerve was probed, the acoustical stimuli were generated by TDT system and delivery to a MF1 speaker. Cochlear amplification was achieved through an amplifier, averaged 1024 times. The CAPs were evoked at $16 \mathrm{kHz}$ tone burst and threshold was obtained. The amplitude and latency of the first positive peak (P1) amplitude were measured. All experiments were carried out in a doublewalled sound-attenuating room.

\section{Statistical analysis}

Data was analyzed by SPSS version 17.0 software (SPSS Inc., Chicago, IL, USA) and plotted using GraphPad prism 7 (Graphpad, USA), and expressed as mean \pm SD. Quantitative data statistical analysis was performed by one-way ANOVA followed by post-hoc tests (as appropriate) for multiple group comparisons, independent samples $t$ test and nonparametric test (Mann-Whitney U test) for two-group data. ${ }^{*} p<0.05$, ${ }^{* *} p<0.01$ and ${ }^{* * * *} p<0.001$ were considered to indicate a statistically significance.

\section{Results \\ Disruption of SCN11A}

Nav1.9 KO mice were genotyped by PCR using genomic DNA from ear marginal tissue. Primer pair 1 and primer pair 2 was used to specifically distinguish WT and Nav1. $9^{-/-}$genotypes. The resulting products of WT, Nav1. $9^{+/-}$and Nav1. $9^{-/-}$were analyzed by agarose gel electrophoresis (Fig. 1b and Additional file 1: Fig. S4). The deletion of $347 \mathrm{bp}$, starting in exon 3 and ending in exon 5 of the coding sequence of SCN11A mRNA, induced a truncated form of Nav1.9 with 96 amino acid residues, and led to the reading frame shift mutation followed by a premature translational-termination codon (Fig. 1c). The mutation resulted in dysfunction of the protein with no membrane-spanning domain. No significant phenotypic difference was found in Nav1.9 $9^{-/-}$mice from WT littermates in their size, weight, coat color, locomotor activity, eating or drinking behavior, fertility and life span. Besides, necropsy and histology between Nav1.9 $9^{-/-}$ and WT mice were considered indistinguishable, apart from a poor protein expression of Nav1.9 in the cochlea of Nav1. $9^{-/-}$mice (Fig. 1d and Additional file 1: Fig. S5).

\section{Nav1.9 is expressed in the inner ear and auditory pathway of wild-type mice}

The expression of Nav1.1 and Nav1.9 mRNA from modiolus was examined using qPCR in WT mice from P0 to P60 (5 mice in each time point). During cochlea development, the expression of Nav1.9 showed no significant difference at P7, P14, P28 and P60 (Fig. 2a, oneway ANOVA, $F=1.673, p=0.18$ ). However, the relative expression levels of Nav1.1 mRNA at P14 and P60 
were significantly higher than that at P0 (Fig. 2a, oneway ANOVA with Tamhane's post-hoc test, " $p=0.028$, "** $p=0.004$ ).

The localization of Nav1.9 in the cochlea was primary afferent and efferent endings in the organ of Corti, SGN somata and cochlear nucleus (Fig. 2b). The immunostaining for Nav1.9 can be seen in inner spiral fibers beneath the inner hair cells (IHCs), radial fibers innervating IHCs, tunnel crossing fibers and outer radial fibers (Fig. 2c, c1, c3 and c4), according to the diagram of the cochlea's afferent innervations pattern from Ballenger's Otorhinolaryngology 18 (Fig. 2c, c2). Besides, some of spiral ganglion neurons (SGNs) that couldn't be stained by anti-MBP antibody (a myelin sheath marker), were immunolabeled for Nav1.9 (Fig. 2d and Additional file 1: Fig. S3). Futhermore, some of neurons within the cochlear nucleus exhibited expression of Nav1.9 on cell membranes at a relatively low density (Fig. 2e), which was consistent with data from previous studies [19].

\section{Nav1.9- $9^{-I-}$ mice are deaf progressively at $16 \mathrm{kHz}$}

ABR was used to assess hearing thresholds in 2-monthold mice. The averaged ABR thresholds of Nav1.9 $9^{+/+}$

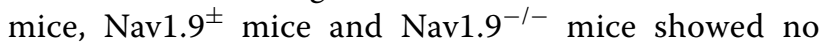
significant difference with each other at $2 \mathrm{kHz}$ (Fig. 3a, one-way ANOVA, $F=2.954, p=0.085)$ and $8 \mathrm{kHz}$ (Fig. 3a, one-way ANOVA, $F=0.576, p=0.571$ ), respec-

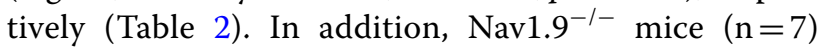
showed a remarkably higher average ABR threshold than Nav1.9 $9^{+-}(\mathrm{n}=4)$ and WT mice $(\mathrm{n}=6)$ by $36.8 \mathrm{~dB}$ SPL $\left({ }^{* * *} p=0.002\right)$ and $38.3 \mathrm{~dB}$ SPL $(* * p=0.001)$ at $12 \mathrm{kHz}$ (Fig. 3a, one-way ANOVA with Bonferroni's post-hoc test), respectively. The average ABR threshold of Nav1.9 $9^{-1-}$ mice was up to $78.9 \pm 10.5 \mathrm{~dB}$ SPL, which is significantly higher than Nav1.9 ${ }^{ \pm}(58.8 \pm 14.9 \mathrm{~dB}$ SPL) (" $p=0.01)$ and WT mice $(41.7 \pm 6.6 \mathrm{~dB}$ SPL) $\left.{ }^{* * * *} p=0.000\right)$ at $16 \mathrm{kHz}$, while the average ABR threshold of Nav1.9 $9^{+/-}$was higher than WT mice $\left({ }^{*} p=0.032\right)$
(Fig. 3a, one-way ANOVA with Bonferroni's post-hoc test) as well. In all mice tested, threshold elevation correlated with reduced amplitudes of all $A B R$ waves at $16 \mathrm{kHz}$ were found in Nav1.9 $9^{-/-}$mice (Fig. 3b).

To examine the onset time of hearing loss, ABR thresholds at the P21, P30, and P60 were measured at 8 and $16 \mathrm{kHz}$, respectively. At $8 \mathrm{kHz}$, the average ABR thresholds of WT mice was $38.7 \pm 5.5(\mathrm{n}=15)$ at P21 and $39.0 \pm 8.1 \mathrm{~dB}$ SPL $(\mathrm{n}=10)$ at P60. The ABR thresholds of Nav1.9 $9^{-1-}$ mice was $39.3 \pm 5.3 \mathrm{~dB}$ SPL $(\mathrm{n}=7)$ at P21 and $36.7 \pm 6.6 \mathrm{~dB}$ SPL $(\mathrm{n}=9)$ at P60. There was no significant difference between the WT and KO mice (Fig. 3c, $t=-0.248, p=0.807$ at P21; $t=0.087, p=0.932$ at P30; $t=0.683, p=0.504$ at $\mathrm{P} 60$ with independent samples $t$ test); At $16 \mathrm{kHz}$, the ABR threshold of WT mice was $30.0 \pm 8.5 \mathrm{~dB}$ SPL $(\mathrm{n}=15)$ at P21, which was significantly lower than their Nav1.9 $9^{-/-}$littermates of $44.3 \pm 8.9 \mathrm{~dB}$ SPL $(\mathrm{n}=7) \quad(U=14.5, \quad Z=-2.751, * * n=0.006$ with

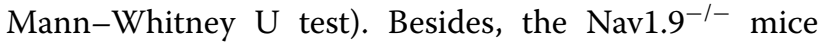
showed a significant ABR threshold elevation compared with their WT littermates at P30 $(72.9 \pm 17.5 \mathrm{~dB}$ SPL $(\mathrm{n}=12)$ vs. $40.0 \pm 9.1 \mathrm{~dB}$ SPL $(\mathrm{n}=4), U=4.5, Z=-2.406$, " $p=0.016$ with Mann-Whitney U test Fig. $3 \mathrm{~d}$ ), and at P60 (78.9 $\pm 10.5 \mathrm{~dB}$ SPL $(\mathrm{n}=9)$ vs. $41.7 \pm 6.6 \mathrm{~dB}$ SPL ( $\mathrm{n}=9), U=0.000, Z=-3.608,{ }^{*} * 0=0.000$ with MannWhitney U test Fig. 3d). The ABR threshold shifts of Nav1. $9^{-/-}$mice in comparison with WT littermates, were 14.3 dB SPL at P21, 32.9 dB SPL at P30, and $37.2 \mathrm{~dB}$ SPL at P60, respectively, exhibiting progressive hearing loss (Table 3).

\section{CAP recording}

In order to identify the lesion region of hearing loss affected by Nav1.9, the CAP was recorded from the round window of cochlea. The average threshold of CAP

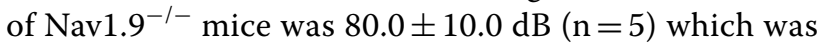
significantly higher than the WT mice $(45.0 \pm 11.5 \mathrm{~dB}$ SPL, $\quad \mathrm{n}=4) \quad(U=0.000, \quad Z=-2.491, \quad$ " $p=0.013$ with Mann-Whitney $U$ test, Fig. 4a). The average

\footnotetext{
(See figure on next page.)

Fig. 2 Distribution of Nav1.9 in primary auditory afferents. a The voltage-gated sodium channel Nav1.9 and Nav1.1 mRNA levels in modiolus of WT ICR mice at the postnatal $0,7 \mathrm{th}, 14 \mathrm{th}, 21 \mathrm{th}, 28 \mathrm{th}$ and 60 th day. Each time point contains 5 mice. ${ }^{*} p=0.028,{ }^{* *} p=0.004$. $\mathbf{b}$ A schematic representing the localization of Nav1.9 channels at primary afferent peripheral nerve endings on hair cells in cochlea, in SGN somata, in the auditory nerve located within the modiolus, and in the cochlear nuclei. c Nav1.9 is present in cochlea basilar membrane by surface preparation technique and immunofluorescence staining in cryo-section. c1 Horizontal section showing three rows of OHCs and one row of IHCs. In a linear distribution below the IHCS, Nav1.9 (purple) is in the afferent endings beneath the IHC bases. Also stained are the afferent radial fibers leading through the tunnel of Corti to their first hemi-nodes beneath the foramina nervosa. Scales $=75 \mu \mathrm{m}$. c2 The diagram of the cochlea's afferent innervations pattern. c3 Nav1.9 is in the nerve endings of internal spiral fibers or radial fibers beneath IHC (red), the cilia of which exhibit phalloidin labeling (green). Scales $=50 \mu \mathrm{m}$. c4 The high magnification image of c3. Scale $=10 \mu \mathrm{m}$. $\mathbf{d}$ The expression of Nav1.9 in the SGNs of P60 WT mouse was measured by immunofluorescence. Nav1.9, MBP, and cell nucleus are stained as red, green and blue, respectively. e Some neurons from the dorsal cochlear nucleus are labeled by Nav1.9 (red)
} 


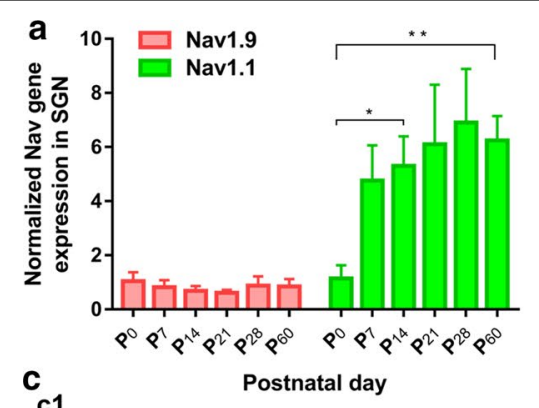

b

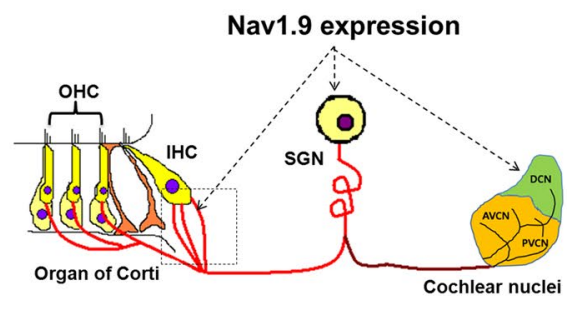

c2
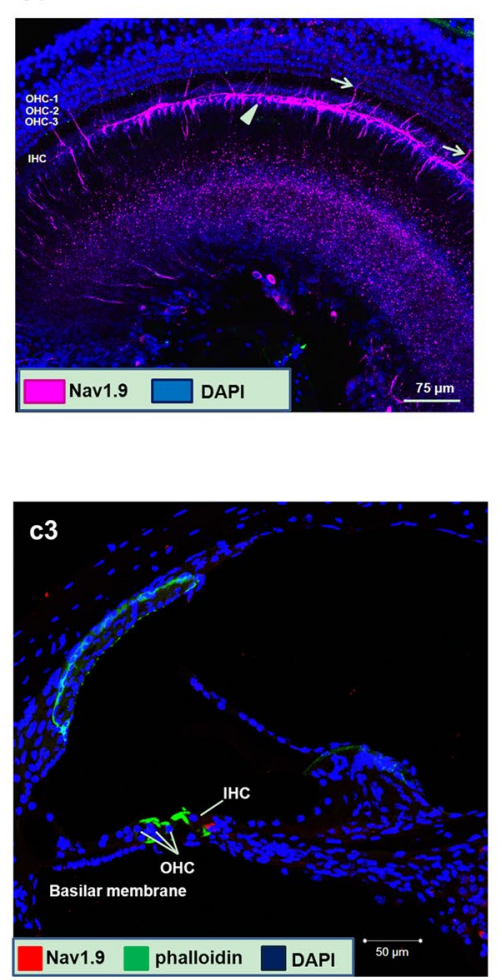

d
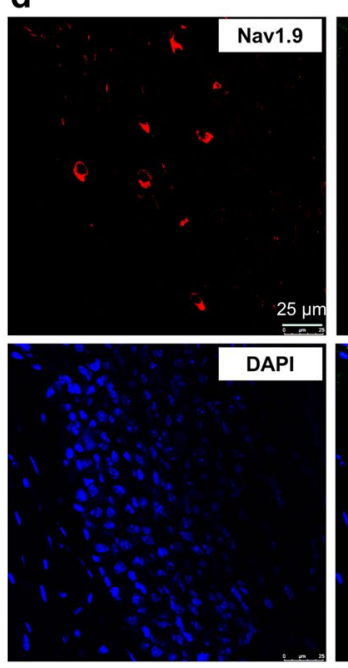

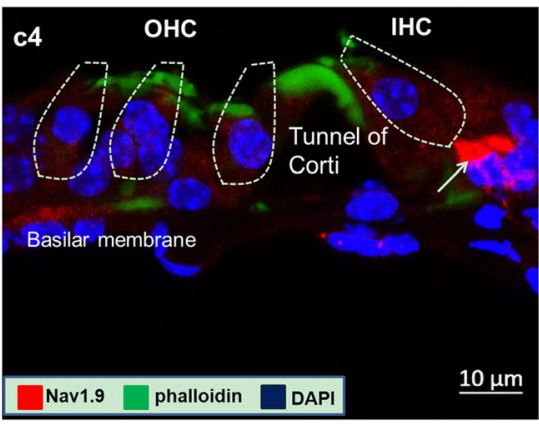

e
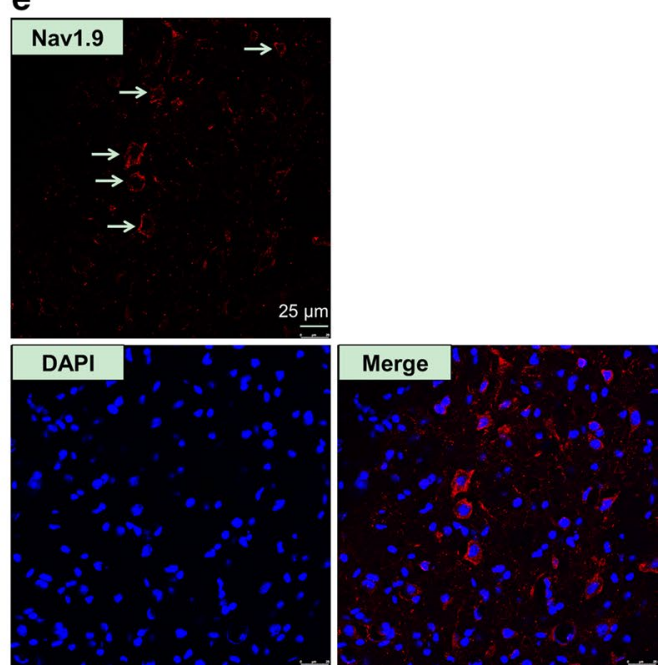

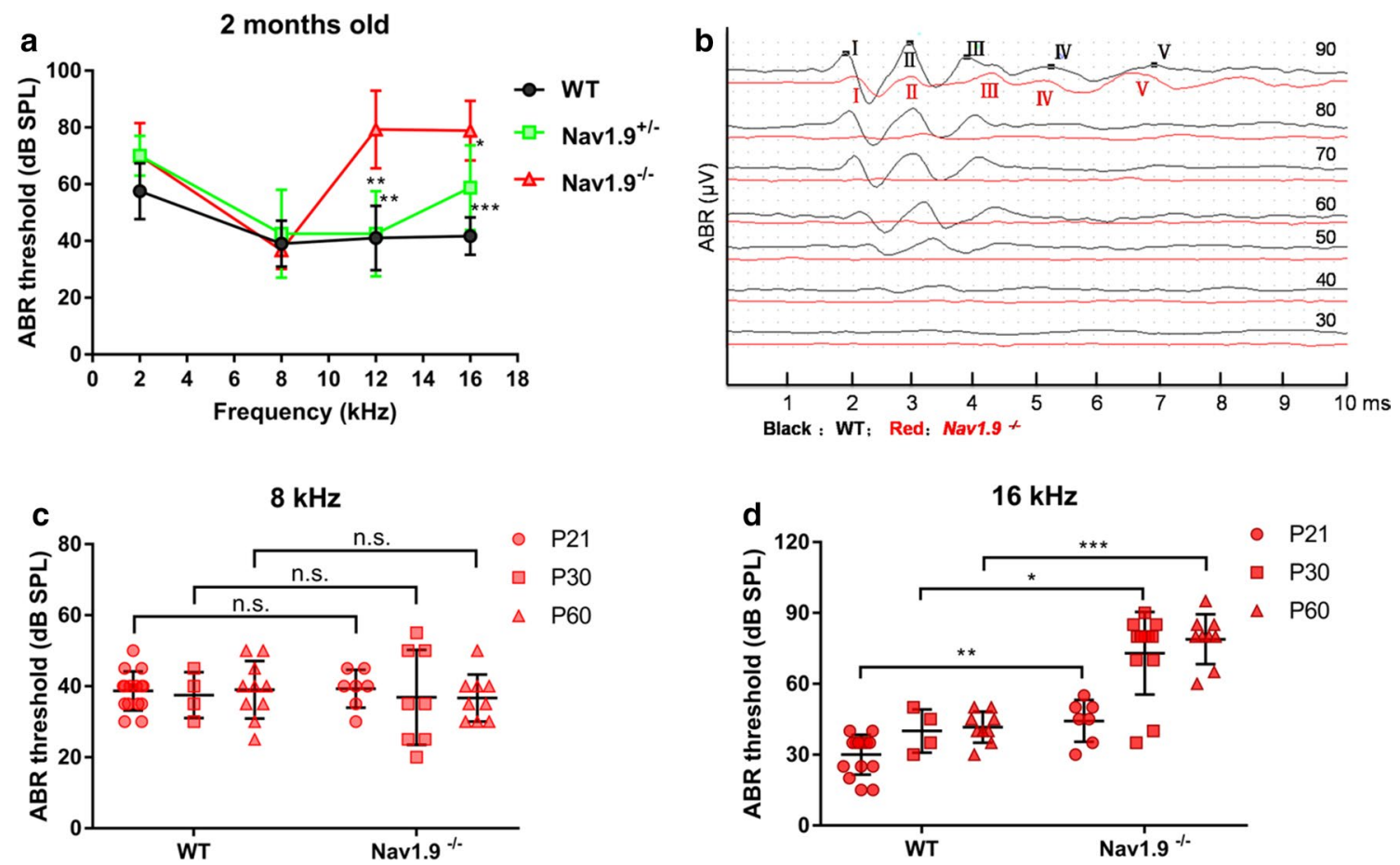

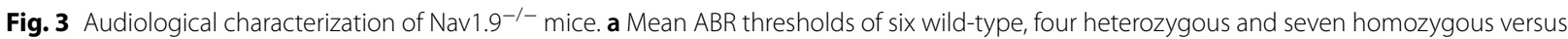
sound frequency, ${ }^{* *} p=0.002,{ }^{* *} p=0.001$ at $12 \mathrm{kHz}$ compared with homozygous, ${ }^{*} p=0.01,{ }^{* * *} p=0.000$ at $16 \mathrm{kHz}$ compared with homozygous by one-way ANOVA with Bonferroni's post-hoc test. $\mathbf{b}$ Example of ABR waveforms at $16 \mathrm{kHz}$ in one ear of a wild-type superimposed on an example of ABR waveforms in one ear of Nav1.9 $9^{-1-}$ mice. c ABR thresholds of WT and homozygous mice of postnatal day 21 to 60 at 8 kHz. $p=0.807$ at P21; $p=0.932$ at P30; $p=0.504$ with independent samples $t$ test; $n$.s.: not significant. $\mathbf{d}$ ABR threshold of WT and homozygous mice of postnatal day 21 to 60 at $16 \mathrm{kHz} .{ }^{*} p=0.016,{ }^{* *} p=0.006,{ }^{* * *} p=0.000$ with Mann-Whitney test. Data are expressed as mean \pm s.d

Table 2 ABR thresholds in Nav1.9+/+ $(\mathrm{WT}),{ }^{+/-},-/-$mice at 2 months of age

\begin{tabular}{lllll}
\hline Group & \multicolumn{4}{l}{ Frequency $(\mathrm{kHz})$} \\
\cline { 2 - 5 } & 2 & 8 & 12 & 16 \\
\hline Nav1.9 & & & \\
Nav1.1 & $57.5 \pm 9.9$ & $39.0 \pm 8.1$ & $41.0 \pm 11.4^{* *}$ & $41.7 \pm 6.6^{* * *}$ \\
Nav1.9 & $70.0 \pm 7.1$ & $42.5 \pm 15.5$ & $42.5 \pm 15.0^{* *}$ & $58.8 \pm 14.9^{*}$ \\
\hline & $70.0 \pm 11.5$ & $36.7 \pm 6.6$ & $79.3 \pm 13.7$ & $78.9 \pm 10.5$
\end{tabular}

Asterisks indicate significant differences $\left({ }^{*} p<0.05,{ }^{* *} p<0.01,{ }^{* * *} p<0.001\right)$ as compared with the Nav1.9 $9^{-/-}$group

Table 3 ABR thresholds in Nav1.9 $9^{+/+,-/-}$mice at different age

\begin{tabular}{|c|c|c|c|c|}
\hline \multirow[t]{2}{*}{ Age (day) } & \multicolumn{2}{|l|}{$8 \mathrm{~K}$} & \multicolumn{2}{|l|}{$16 \mathrm{~K}$} \\
\hline & WT & Nav1.9- $9^{-/-}$ & WT & Nav1.9-1- \\
\hline P21 & $38.7 \pm 5.5$ & $39.3 \pm 5.3$ & $30.0 \pm 8.5$ & $44.3 \pm 8.9^{* *}$ \\
\hline P30 & $37.5 \pm 6.5$ & $36.9 \pm 13.3$ & $40.0 \pm 9.1$ & $72.9 \pm 17.5^{*}$ \\
\hline P60 & $39.0 \pm 8.1$ & $36.7 \pm 6.6$ & $41.7 \pm 6.6$ & $78.9 \pm 10.5^{* * *}$ \\
\hline
\end{tabular}

Asterisks indicate significant differences $\left({ }^{*} p<0.05,{ }^{* *} p<0.01,{ }^{* * *} p<0.001\right)$ as compared with WT group amplitude in P1 wave of Nav1.9 $9^{-/-}$mice at $80 \mathrm{~dB}$ SPL was $4.6 \pm 3.9 \mu \mathrm{V}(\mathrm{n}=5)$ which was significantly lower than that form the WT mice $(22.1 \pm 15.6 \mu \mathrm{V}, \mathrm{n}=5)$, $(t=2.434, " p=0.041$, independent samples $t$ test, Fig. $4 \mathrm{~b})$. In addition, the average latencies of P1 waves from WT and Nav1.9 $9^{-/-}$mice were $2.1 \pm 0.4 \mathrm{~ms}(\mathrm{n}=7)$ and $2.4 \pm 0.4 \mathrm{~ms}(\mathrm{n}=5)$, respectively, with no statistical difference $(t=-1.244, p=0.242$ with independent samples $t$ test) (Fig. 4c). The representative CAP waveforms of WT and Nav1.9 $9^{-/-}$were shown in Fig. 4d, e.

\section{Ribbon synapse counting}

The quantitative changes in ribbon presynaptic RIBEYE were stained using antibodies against CtBP2. The average number of CtBP2 puncta in WT mice $(n=7)$ was $7.3 \pm 2.4$ per IHC, which was statistically higher than that in Nav1.9 $9^{-1-}$ mice with $4.2 \pm 1.6$ per IHC $(\mathrm{n}=5)(U=4.5, Z=-2.122$, " $p=0.034$, Mann-Whitney $\mathrm{U}$ test, Fig. $5 \mathrm{a}-\mathrm{c}$ ). This data indicates that Nav1.9 $\mathrm{KO}$ induced auditory deficits by a mechanism including cochlear synaptopathy. 

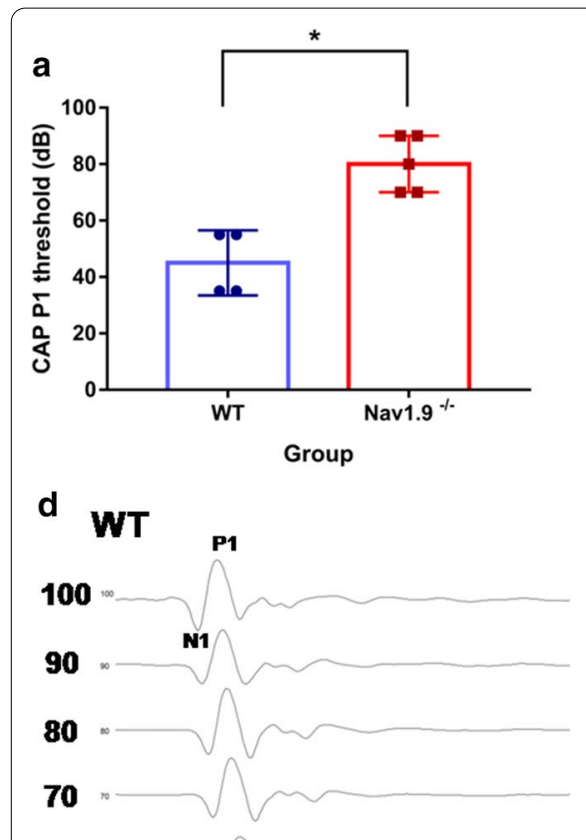

60

50

40

35

30
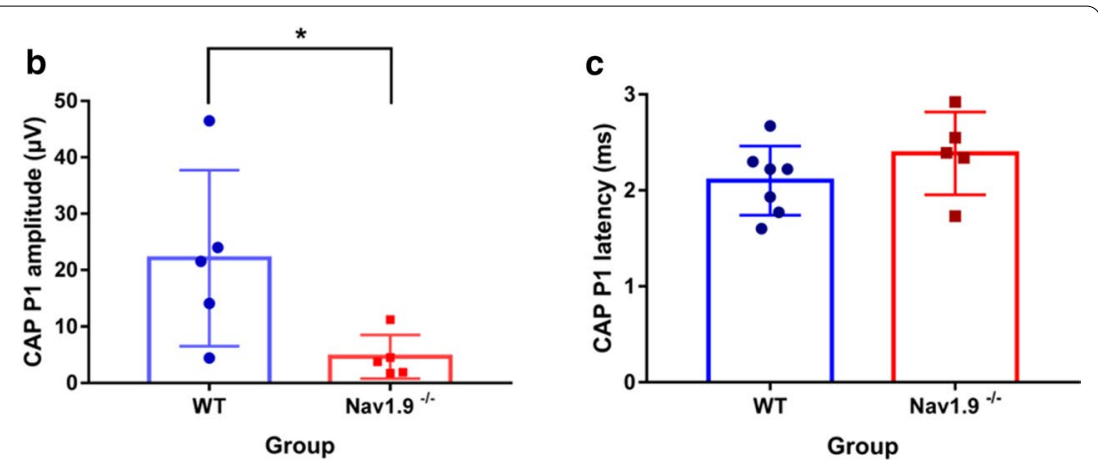

e

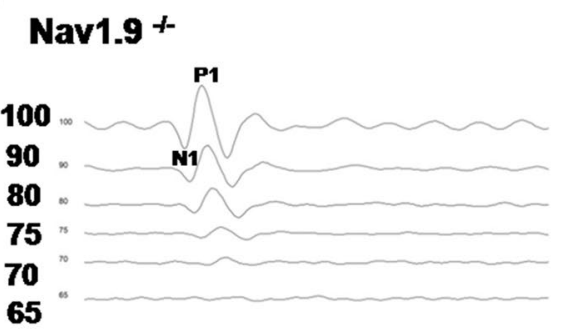

Fig. 4 Auditory compound action potentials are affected by Nav1.9 knockout. Nav1.9 knockout induces higher CAP P1 threshold, ${ }^{*} p=0.013$ with Mann-Whitney test (a), lower CAP P1 amplitude, ${ }^{*} p=0.041$ with independent samples $t$ test $(\mathbf{b})$, compared with WT group; $\mathbf{c}$ the CAP P1 latency is not affected at the time point of postnatal day $60, p=0.242$ with independent samples $t$ test. $\mathbf{d}$ Representative CAP waveforms from a WT mouse. $\mathbf{e}$ Representative CAP waveforms from a Nav1.9 $9^{-/-}$mice. Data are expressed as mean \pm s.d

\section{SGN counting}

The number of spiral ganglion neurons (SGNs) was counted. The average number of the SGNs in the basal turn of cochlea of Nav1.9 $9^{-/-}$mice $(\mathrm{n}=4)$ was $37.0 \pm 3.1$, which is significantly lower than that of WT mice $(n=5)$ with 51.0 $5.8(U=0.000, Z=-2.46, " p=0.014$, MannWhitney $U$ test, Fig. $5 \mathrm{~d}-\mathrm{f})$. However, the number of SGNs in both apical ( $t=0.518, p=0.622$ with independent samples $t$ test) and middle turn $(t=0.703, p=0.823$ with independent samples $t$ test) showed no statistical difference between the two groups. The average numbers of SGN were $45.8 \pm 4.7 \mathrm{in}$ apex and $53.8 \pm 8.2 \mathrm{in}$ middle for Nav1.9 $9^{-1-}$ mice; $48.3 \pm 9.3$ in apex and $54.6 \pm 11.2$ in middle for WT mice, which was in accordance with impaired temporal neural code at high frequency, such as $16 \mathrm{kHz}$.

\section{Nav1.9 knockout with intact OHCs}

Nav1. $9^{-1-}$ mice had spared outer hair cells (OHCs) function of mechanoelectrical transduction and cochlear amplification. To explore the hair cell morphology in the region of ABR threshold shift, a standard cochleogram of a 4 months old Nav1.9 $9^{-/-}$mouse was provided (Fig. 6a), containing scales of frequency, percent distance from the apex according to Müller et al. [22] (Fig. 6b). No significant hair cell missing from base to apex was found in cochleograms from DAPI staining, especially in the middle turn (30-55\% distance from the apex) (Fig. 6c). Subsequently, we investigated the morphology of inner and outer hair cell stereocilia by scanning electron microscopy. Adult Nav1.9 $9^{-1-}$ mice at 2 months had well-formed and evenly spaced stereocilia bundles, with an equal height within each row in the apical (Fig. 6d, b1-b3) middle (Fig. 6d, b4b6), and basal turn as well (Fig. 6d, b7-b9).

\section{Discussion}

This paper we have three novel findings on the expression and function of Nav1.9 in auditory system. (1) Nav1.9 was detected in the SGNs somatathat couldn't be immunolabeled by MBP; (2) Nav1.9 KO mice showed a high frequency hearing loss at 2 months age. (3) Morphology experiments demonstrated reduced synapses and number of auditory nerves in the basal turn of the cochlea in Nav1.9 KO mice. 


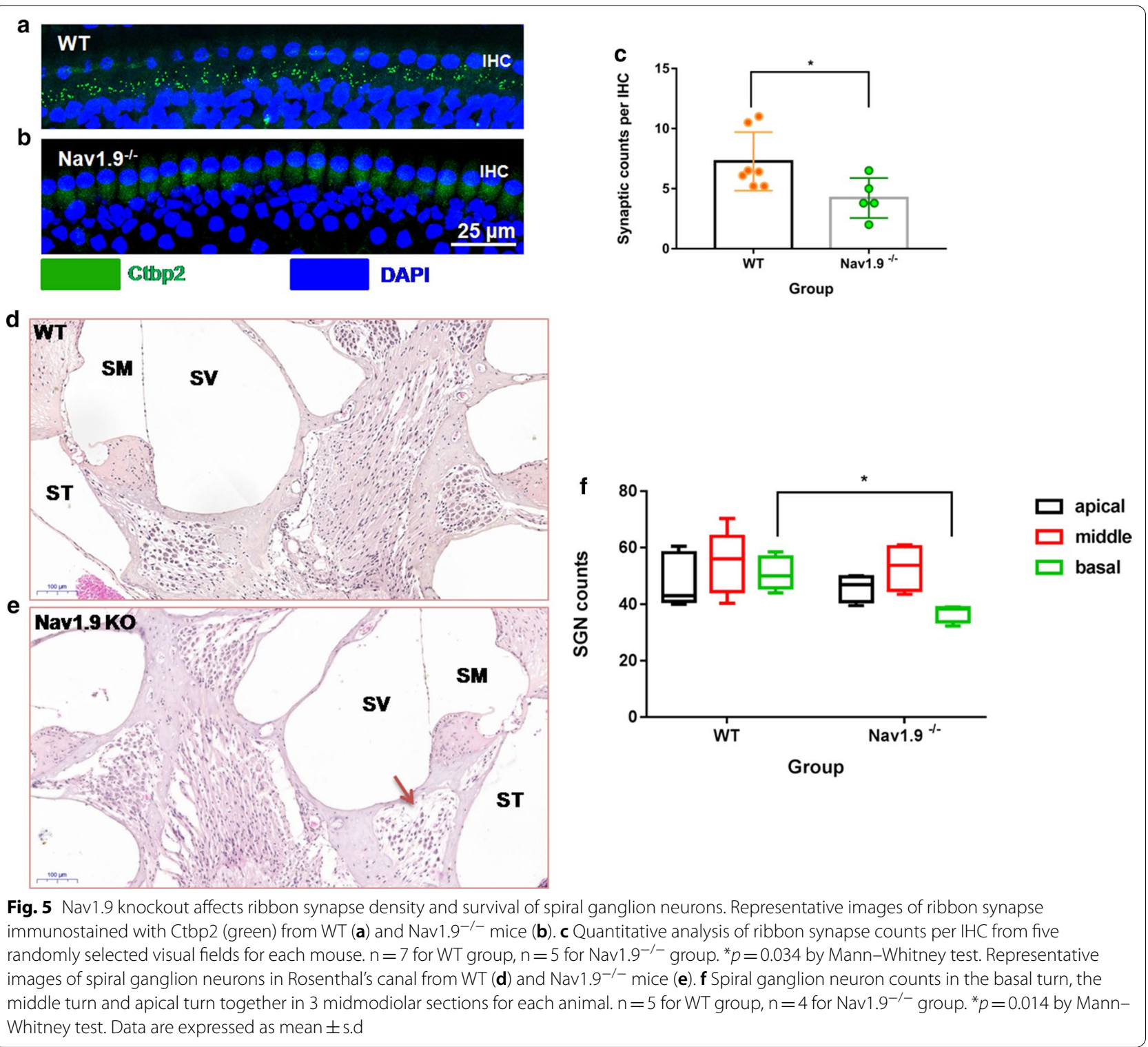

\section{Nav1.9 is predominantly present in peripheral auditory nerve}

We found that Nav1.9 was located in nerve terminals in a plane beneath the IHCs. Also stained are the afferent radial fibers leading through the foramina nervosa (FN) (Additional file 1: Fig. S1), and a small part of SGNs somata, their peripheral and central initial segments. The distribution of Nav1.9 detected in the dorsal cochlear nucleus was consistent with a previous study [19]. In addition, Nav1.9 labeled fibers run longitudinally beneath the IHCs among scattered CtBP2 in the presynaptic membrane (Additional file 1: Fig. S2), suggesting that this sodium channel may play a role in modulating neurotransmitter such as glutamic acid in presynaptic membrane. This hypothesis was consistent with less heat-induced calcitonin gene-related peptide release form the skin in Nav1.9 KO mice. Alternatively, Nav1.9 may affect the ribbon synapse plasticity as well.

The distribution of Nav1.9 in auditory afferent nerve is similar to that in functionally identified nociceptors [29]. The localization of Nav1.9 channels at primary afferent peripheral nerve endings in the skin, is in analogy to that in afferent nerve ending beneath the IHCs; Nav1.9 in DRG somata is in analogy to that in SGN somata; Nav1.9 is expressed in central nerve endings in the dorsal horn of the spinal cord, in analogy to that in dorsal cochlear nucleus. However, more evidences that Nav1.9 distributes in auditory primary afferent are still needed. 


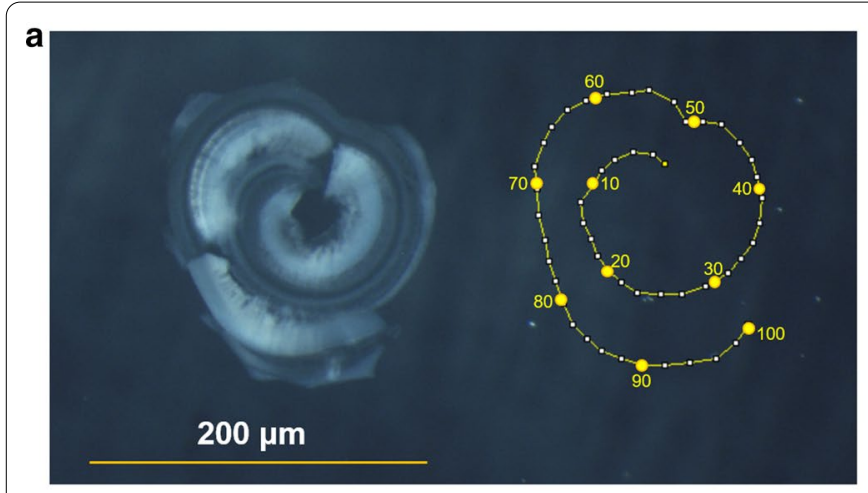

b
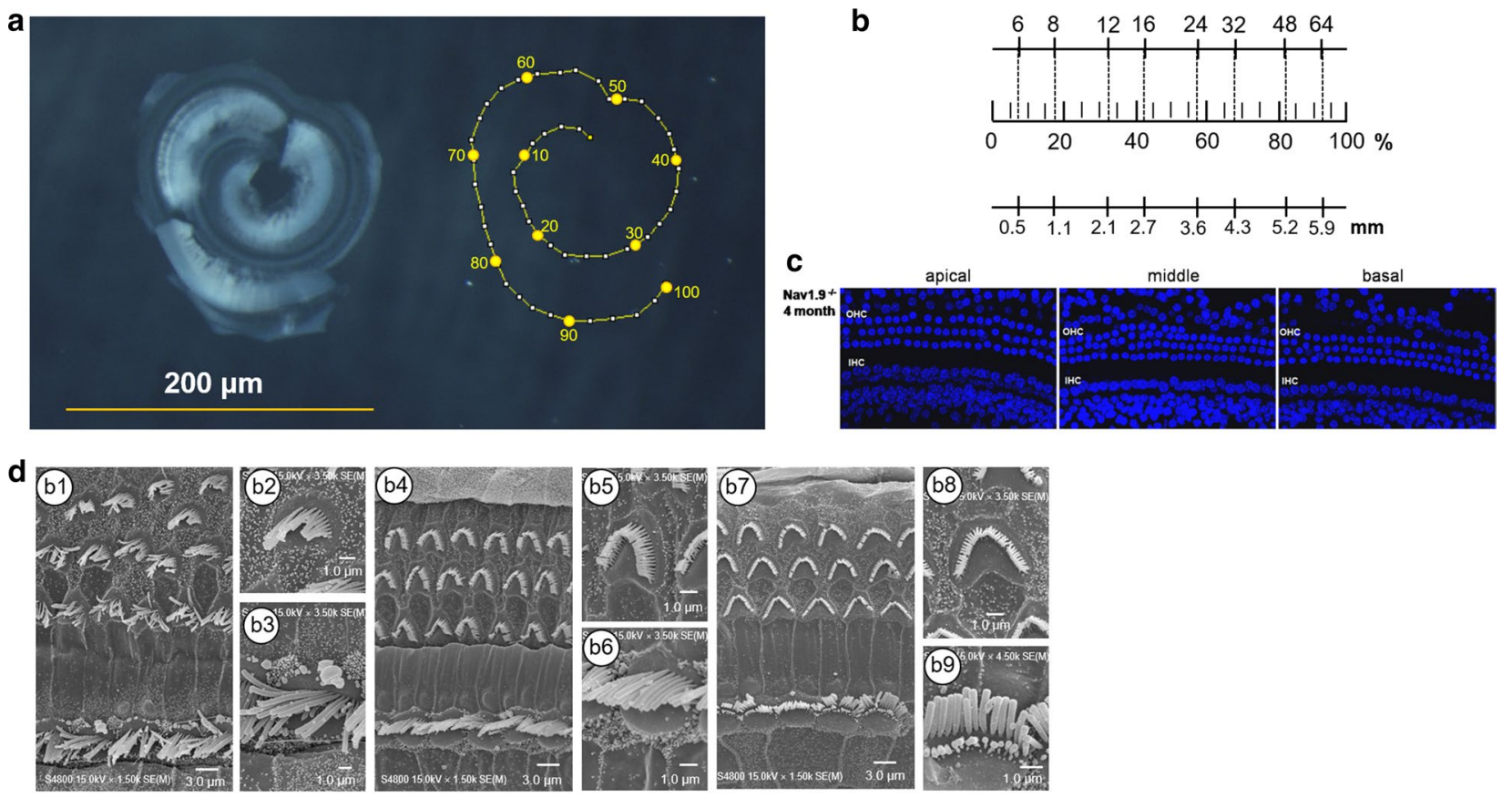

Fig. 6 Nav1.9 knockout does not affect the morphology of hair cells. a The digital image of a dissected cochlea including the hook region (left) from a 4 months old mouse. Schematic drawing of the same cochlea with percent distance from the apex plotted (right). $\mathbf{b}$ Scale is showing frequency, percent distance from the apex, and distance $(\mathrm{mm})$, according to Müller et al. [22]: $x=100-(156.53-82.46 * \log (\mathrm{F}))$. The full basilar membrane length is $6.3 \mathrm{~mm}$ for this particular cochlea. C, Images of organ of Cortis from 4 months old mice stained by DAPI (blue), with the apical turn (0-25\% distance from the apex), the middle turn (30-55\% distance from the apex) and the basal turn (60-85\% distance from the apex). $\mathbf{d}$ Images of the organ of Corti of Nav1.9 $9^{-/-}$mice at postnatal ages of 2 months by SEM, containing the apical turn (b1-b3), the middle turn (b4-b6), and the basal turn (b7-b9)

Furthermore, as one of Nav channels specifically expressed in the peripheral nervous system, Nav1.9 may be expressed with unique patterns. Unlike Nav1.6 which is localized in the outer spiral fibers and their sensory endings beneath the OHCs, and Nav1.2 which is localized to the unmyelinated efferent axons and their endings on the IHCs and OHCs, Nav1.9 is predominantly present in the inner spiral fibers beneath the IHCs, which consist of distinctive neuronal plexus (glutamic acid decarboxylase (GAD)-positive fibers and gamma-aminobutyric (GABA)-positive fibers) intimately associated with IHCs [30]. Compared with mRNA expression of Nav1.1, which is a main contributor to auditory nerve spike generation [31], the expression of Nav1.9 mRNA was much lower at P7 at the onset of hearing. The different expression profile of Nav1.9 with Nav1.1, suggests that this channel may contribute less to the action potentials generation. Third, Nav1.9 KO mice showed elevated CAP thresholds compared to the WT mice. Moreover, the decreased amplitudes of CAP may result from loss of neural activity, as a result of a decrease in SGN count in Nav1.9 KO mice. Therefore Nav1.9 channels may serve as an amplifier of receptor potentials, facilitating neuronal excitation, rather than contributing to action potential generation.

\section{Nav1.9 knockout mice show reduced ribbon synapses}

The average number of ribbon synapse in adult Nav1.9 KO mice was lower than their WT littermates. All synaptic ribbons contain a unique ribbon-specific scaffolding protein called RIBEYE, which contains a C-terminal $\mathrm{B}$-domain that is identical with the transcription factor CtBP2 [32]. The reduced CtBP2 intensity in Nav1.9 KO mice suggests that Nav1.9 is essential for integrity of presynaptic nano-domains that position release-ready synaptic vesicles. An analogy to this hypothesis is the possible role of Nav1.9 in modulating neurotransmitter release in the dorsal horn of the spinal cord at the first synapse mediating pain signaling [29]. The mechanism of Nav1.9 in modulating morphology and function of ribbon synapse is still ambiguous. One candidate factor neurotrophin-3 (Ntf3) has been reported to regulate ribbon synapse density in the cochlea. Supporting cellderived Ntf3 promotes ribbon synapse regeneration after acoustic trauma [33]. In the CCI model of neuropathic 
pain, Ntf3 is capable of attenuating expression of Nav1.9 mRNA and protein [34], indicating a possible ability of Ntf3 modulating the plasticity of ribbon synapse via Nav1.9 in cochlea.

Knockout of Nav1.9 induces postsynaptic degradation including loss of both ribbon synapse and SGNs, which may not affect the activity of OHCs. Although Nav1.9 distributes tunnel fibers to OHCs, knockout alleles doesn't cause significant OHCs loss or dysfunction, due to the possible compensation of other sodium channels such as Nav1.2 or Nav1.6 tracking afferent innervation of OHCs [35].

\section{Nav1.9 knockout mice have progressive hearing loss in high frequency}

This study showed Nav1.9 knockout mice with profound hearing loss at $16 \mathrm{kHz}$ as early as 1 month after birth, while at $8 \mathrm{kHz}$ no significant acoustic trauma was found from 21 days to 2 months after birth. Redox imbalance induced progressive haring loss was explored in a Dusp 1 deficient mouse model, which progressively trigger inflammation and apoptotic cell death [36]. It is implied that Nav1.9 knockout may trigger a stress imbalance. In support of this hypothesis, the current density of Nav1.9 was increased by inflammatory mediators, such as interleukin-1 $\beta$ [37], thus rendering DRG neurons hyperexcitable and leading to pain in inflammatory disorders.

Hearing loss in high frequency may result from reduced SGNs in the basal turn by affecting the cellular survival or development in Nav1.9 knockout mice. One explanation may be that the neurotrophins neurotrohin-3 (NT-3) and brain-derived neurotrophic factor (BDNF) could regulate the gradient expression of Nav1.9 in the organ of Corti. Both BDNF and NT-3 expressed in the cochlea support SGN survival during development. As NT-3 expression is highest in the cochlear apex and lowest in the base, and high expression on the modiolus side, the negative regulation might contribute to the higher expression level of Nav1.9 in the base. BDNF, the receptor tyrosine kinase (TrkB) and Nav1.9 has been reported as a gating mechanism in both hippocampal neurons in CNS and SH-SY5Y line [9]. Nav1.9 knockout may have significant effect on the survival of SGN in the base, through reduction of BDNF-TrkB-Nav1.9 pathway. The exact mechanism why Nav1.9 knockout affected SGN survival in the basal turn, rather than the middle and apex, is still unclear.

\section{Conclusions}

For the first time, our study provides evidence that Nav1.9 is expressed in SGNs and essential for high frequency hearing in the mouse cochlea. Since transcriptome analysis shows that SCN11A is expressed in SGNs in neonatal and adult mice [38-40], it would be interesting to determine if Nav1.9 is expressed in type I or type II SGNs or both. It is also interesting to determine if Nav1.9 is related to the fibers with low and medium rates or high levels of spontaneous activity. Although transcriptome analysis shows that $S C N 11 A$ is still expressed in adult hair cells [41, 42], we speculate that reduced number of presynaptic CtBP2 is secondary to loss of SGN terminals in the basal turn in Nav1.9 KO mice. But our study does suggest Nav1.9 function can affect the survival of SGN. The precise mechanism of Nav1.9 in modulating auditory neural function deserves further study.

\begin{abstract}
Abbreviations
KO: Knockout; SGNs: Spiral ganglion neurons; ABR: Auditory brainstem response; ECochGs: Electrocochleogram recordings; IHCs: Inner hair cells; OHCs: Outer hair cells; WT: Wild-type; CAP: Compound action potential; SAPs: Single action potentials; DRG: Dorsal root ganglion; BDNF: Brain-derived neurotrophic factor; CMH: C mechano-heat-sensitive; Atoh 1: Atonal homolog 1a; CWCs: Cartwheel cells; DCN: The dorsal cochlear nucleus; DSB: Doublestrand break; gRNAs: Single-guide RNAs; FN: Foramina nervosa.Supplementary Information
\end{abstract}

The online version contains supplementary material available at https://doi. org/10.1186/s12868-021-00613-8.

Additional file 1: Figure S1. The expression of Nav1.9 is located in spiral bundles beneath the IHCs bases. A, Horizontal section showing Nav1.9 (red) in the afferent endings and in the afferent radial fibers leading through the FN (arrow). B, Cross section showing Nav1.9 (red) labeling afferent radial fibers leading through the FN (arrow). T: the tunnel of Corti; PP: the phalangeal processes. Figure S2. Nav1.9 labeling spiral bundles run among scattered CtBP2 puncta in presynaptic membrane. A, Staining with DAPI in cochlea basilar membrane. B, Immunostaining with Nav1.9 (red), containing radial bundles (arrow) and suspected afferent (dashed arrow) from unmyelinated Type II ganglion cells cross the tunnel of Corti (T) to innervate OHCs. C, Immunostaining with CtBP2 (green) puncta beneath IHCs (arrowhead). D, Bright field of cochlea basilar membrane, showing one row of $\mathrm{OHCS}$, the phalangeal processes (PP), and one row of IHCs. E, Image with overlapping fluorescent channels. Scale $=25 \mu \mathrm{m}$. Figure S3. Anti-MBP antibody labeling myelin sheath covering type I afferent and neuron soma (Green). BF: bright field. Immunostaining with MBP (green) in type I afferent fibre (arrow), and type I SGN soma (arrowhead) are shown, respectively. Figure $\mathbf{S 4}$. The genotype was identified by PCR. Line M: DL2000 DNA Marker; Line 1: the PCR product of tissue from WT mouse with Prime 2 (shortened to "WT with Primer 2"); Line 2: WT with Primer 1; Line 3: heterozygous with Primer 2; Line 4: heterozygous with Primer 1; Line 5: homozygous (female) with Primer 2; Line 6: homozygous (female) with Primer 1; Line 7: homozygous (male) with Primer 2; Line 8: homozygous (male) with Primer 1. Figure S5. The expression of Nav1.9 in the cochleas of Nav1.9-1- mice $(n=3)$ or WT mice $(n=4)$ was measured by western blot.

\section{Acknowledgements}

We thank Dr. Ning Yu (Chinese PLA Institute of Otolaryngology) and Qing Chang (CasGene Biotech. Co., Ltd) for technical supports.

\section{Authors' contributions}

MZ, WGS, SMY designed the work. WWG interpreted data. MZ, TC, FJ, SLZ performed experiments. YZ provided technical assistance. XS, MZ analyzed raw data. SMY, WS and DZZH substantively revised the manuscript. MZ, WS wrote original draft. All authors read and approved the final manuscript. 


\section{Funding}

This work was supported by grants from the National Natural Science Foundation of China (NSFC \#81670940), Key International (Regional) Joint Research Program of National Natural Science Foundation of China (NSFC\#81820108009) and Special Cultivating and Developing Program of Beijing Science and Technology Innovation Base (z151100001615050). The funding bodies played no role in the design of the study and collection, analysis, and interpretation of data and in writing the manuscript.

\section{Availability of data and materials}

The datasets generated and/or analyzed during the current study are available from the corresponding author on reasonable request.

\section{Ethics approval and consent to participate}

All animal procedures in this work were carried out in accordance with the Policy on Human Care and Use of Laboratory Animals at PLA General Hospital and approved by the Institutional Animal Care and Use Committee (process no. 2018-X14-84).

\section{Consent for publication}

Not applicable.

\section{Competing interests}

The authors declare that they have no competing interests.

\section{Author details}

${ }^{1}$ College of Otolaryngology Head and Neck Surgery, Chinese PLA General Hospital, Beijing, China. ${ }^{2}$ National Clinical Research Center for Otolaryngologic Diseases, Beijing, China. ${ }^{3}$ Key Lab of Hearing Science, Ministry of Education, Beijing, China. ${ }^{4}$ Beijing Key Lab of Hearing Impairment for Prevention and Treatment, Beijing, China. ${ }^{5}$ Clinical Hearing Center of Affiliated Hospital of Xuzhou Medical University, Xuzhou, Jiangsu, China. ${ }^{6}$ Department of Communicative Disorders and Sciences, Center for Hearing and Deafness, The State University of New York at Buffalo, Buffalo, NY, USA. ${ }^{7}$ Department of Biomedical Sciences, Creighton University School of Medicine, Omaha, NE 68178, USA.

${ }^{8}$ State Key Laboratory of Toxicology and Medical Countermeasures, Beijing Institute of Pharmacology and Toxicology, Beijing, China.

Received: 30 July 2020 Accepted: 20 January 2021

Published online: 22 March 2021

\section{References}

1. Akopian AN, Sivilotti L, Wood JN. A tetrodotoxin-resistant voltagegated sodium channel expressed by sensory neurons. Nature. 1996;379(6562):257-62.

2. Dib-Hajj SD, Tyrrell L, Waxman SG. Structure of the sodium channel gene SCN11A: evidence for intron-to-exon conversion model and implications for gene evolution. Mol Neurobiol. 2002;26(2-3):235-50.

3. Tyrrell L, Renganathan M, Dib-Hajj SD, Waxman SG. Glycosylation alters steady-state inactivation of sodium channel Nav1.9/NaN in dorsal root ganglion neurons and is developmentally regulated. J Neurosci. 2001;21(24):9629-37.

4. Xu W, Zhang J, Wang Y, Wang L, Wang X. Changes in the expression of voltage-gated sodium channels Nav1.3, Nav1.7, Nav1.8, and Nav1.9 in rat trigeminal ganglia following chronic constriction injury. NeuroReport. 2016;27(12):929-34

5. Thun J, Persson AK, Fried K. Differential expression of neuronal voltagegated sodium channel mRNAs during the development of the rat trigeminal ganglion. Brain Res. 2009;1269:11-22.

6. O'Donnell AM, Coyle D, Puri P. Decreased Na(v)1.9 channel expression in Hirschsprung's disease. J Pediatr Surg. 2016;51(9):1458-61.

7. O'Brien BJ, Caldwell JH, Ehring GR, O'Brien KMB, Luo SJ, Levinson SR. Tetrodotoxin-resistant voltage-gated sodium channels $\mathrm{Na}(\mathrm{V}) 1.8$ and $\mathrm{Na}(\mathrm{v}) 1.9$ are expressed in the retina. J Comp Neurol. 2008;508(6):940-51.

8. Delmas P, Coste B. Na+ channel Nav1.9: in search of a gating mechanism. Trends Neurosci. 2003:26(2):55-7.

9. Blum R, Kafitz KW, Konnerth A. Neurotrophin-evoked depolarization requires the sodium channel $\mathrm{Na}(\mathrm{V}) 1.9$. Nature. 2002:419(6908):687-93.
10. Baker MD, Chandra SY, Ding Y, Waxman SG, Wood JN. GTP-induced tetrodotoxin-resistant $\mathrm{Na}+$ current regulates excitability in mouse and rat small diameter sensory neurones. J Physiol. 2003;548(Pt 2):373-82.

11. Cummins TR, Dib-Hajj SD, Black JA, Akopian AN, Wood JN, Waxman SG. A novel persistent tetrodotoxin-resistant sodium current in SNS-null and wild-type small primary sensory neurons. J Neurosci. 1999;19(24):1713-4.

12. Huang J, Vanoye CG, Cutts A, Goldberg YP, Dib-Hajj SD, Cohen CJ, Waxman SG, George AL Jr. Sodium channel NaV1.9 mutations associated with insensitivity to pain dampen neuronal excitability. J Clin Investig. 2017;127(7):2805-14.

13. Hoffmann T, Kistner K, Carr RW, Nassar MA, Reeh PW, Weidner C. Reduced excitability and impaired nociception in peripheral unmyelinated fibers from Nav1.9-null mice. Pain. 2017;158(1):58-67.

14. Petitpre C, Wu HH, Sharma A, Tokarska A, Fontanet P, Wang YQ, Helmbacher F, Yackle K, Silberberg G, Hadjab S, et al. Neuronal heterogeneity and stereotyped connectivity in the auditory afferent system. Nat Commun. 2018;9:1-3.

15. Browne L, Smith K, Jagger D. Identification of persistent and resurgent sodium currents in spiral ganglion neurons cultured from the mouse cochlea. eNeuro. 2017:4(6):ENEURO.0303-17.

16. Lu J, Liu H, Lin S, Li C, Wu H. Electrophysiological characterization of acutely isolated spiral ganglion neurons in neonatal and mature sonic hedgehog knock-in mice. Neurosci Lett. 2019;714:134536.

17. Zhong C, Fu Y, Pan W, Yu J, Wang JF. Atoh1 and other related key regulators in the development of auditory sensory epithelium in the mammalian inner ear: function and interplay. Dev Biol. 2019;446(2):133-41.

18. Yoon H, Lee DJ, Kim MH, Bok J. Identification of genes concordantly expressed with Atoh1 during inner ear development. Anat Cell Biol. 2011:44(1):69-78.

19. Yan $Z, X u Y$, Liang $M$, Ren $X$. Expression and functional role of Nav1.9 sodium channel in cartwheel cells of the dorsal cochlear nucleus. Mol Med Rep. 2015;11(3):1833-6.

20. Zu M, Yang F, Zhou WL, Liu AL, Du GH, Zheng LS. In vitro anti-influenza virus and anti-inflammatory activities of theaflavin derivatives. Antivir Res. 2012;94(3):217-24.

21. Stankovic KM, Corfas G. Real-time quantitative RT-PCR for low-abundance transcripts in the inner ear: analysis of neurotrophic factor expression. Hear Res. 2003:185(1-2):97-108.

22. Müller M, von Huenerbein $K$, Hoidis S, Smolders JWT. A physiological place-frequency map of the cochlea in the mouse. In: Abstract \#423, ARO 27th Annual Midwinter Meeting, Daytona Beach, FI, USA. 2014.

23. Wan GQ, Corfas $\mathrm{G}$. Transient auditory nerve demyelination as a new mechanism for hidden hearing loss. Nat Commun. 2017;8:1-3.

24. Chen W, Hao QQ, Ren LL, Ren W, Lin HS, Guo WW, Yang SM. Cochlear morphology in the developing inner ear of the porcine model of spontaneous deafness. BMC Neurosci. 2018;19:1-8.

25. Landry TG, Wise AK, Fallon JB, Shepherd RK. Spiral ganglion neuron survival and function in the deafened cochlea following chronic neurotrophic treatment. Hear Res. 2011;282(1-2):303-13.

26. Wrzeszcz A, Reuter G, Nolte I, Lenarz T, Scheper V. Spiral ganglion neuron quantification in the guinea pig cochlea using confocal laser scanning microscopy compared to embedding methods. Hear Res. 2013:306:145-55

27. Zu M, Jiang J, Zhao H, Zhang S, Yan Y, Qiu S, Yuan S, Han J, Zhang Y, Guo $W$, et al. Rapid analysis of neomycin in cochlear perilymph of guinea pigs using disposable SPE cartridges and high performance liquid chromatography-tandem mass spectrometry. J Chromatogr B Anal Technol Biomed Life Sci. 2018;1093-1094:52-9.

28. Chen L, Guo W, Ren L, Yang M, Zhao Y, Guo Z, Yi H, Li M, Hu Y, Long X, et al. A de novo silencer causes elimination of MITF-M expression and profound hearing loss in pigs. BMC Biol. 2016;14:52.

29. Dib-Hajj SD, Black JA, Waxman SG. NaV1.9: a sodium channel linked to human pain. Nat Rev Neurosci. 2015;16(9):511.

30. Nitecka LM, Sobkowicz HM. The GABA/GAD innervation within the inner spiral bundle in the mouse cochlea. Hear Res. 1996;99(1-2):91-105.

31. Kim KX, Rutherford MA. Maturation of NaV and KV channel topographies in the auditory nerve spike initiator before and after developmental onset of hearing function. J Neurosci. 2016;36(7):2111.

32. Maxeiner S, Luo FJ, Tan A, Schmitz F, Sudhof TC. How to make a synaptic ribbon: RIBEYE deletion abolishes ribbons in retinal synapses and disrupts neurotransmitter release. EMBO J.2016:35(10):1098-114. 
33. Wan GQ, Gomez-Casati ME, Gigliello AR, Liberman MC, Corfas G. Neurotrophin-3 regulates ribbon synapse density in the cochlea and induces synapse regeneration after acoustic trauma. Elife. 2014;3:e03564.

34. Wilson-Gerwing TD, Stucky CL, Mccomb GW, Verge VMK. Neurotrophin-3 significantly reduces sodium channel expression linked to neuropathic pain states. Exp Neurol. 2008;213(2):303-14.

35. Hossain WA, Antic SD, Yang Y, Rasband MN, Morest DK. Where is the spike generator of the cochlear nerve? Voltage-gated sodium channels in the mouse cochlea. J Neurosci. 2005;25(29):6857.

36. Celaya AM, Sanchez-Perez I, Bermudez-Munoz JM, Rodriguez-de la Rosa L, Pintado-Berninches L, Perona R, Murillo-Cuesta S, Varela-Nieto I. Deficit of mitogen-activated protein kinase phosphatase 1 (DUSP1) accelerates progressive hearing loss. Elife. 2019;8:e39159.

37. Maingret F, Coste B, Padilla F, Clerc N, Crest M, Korogod SM, Delmas P. Inflammatory mediators increase Nav1.9 current and excitability in nociceptors through a coincident detection mechanism. J Gen Physiol. 2008;131(3):211-25.
38. Lu CC, Appler JM, Houseman EA, Goodrich LV. Developmental profiling of spiral ganglion neurons reveals insights into auditory circuit assembly. J Neurosci. 2011;31:10903-18.

39. Sun SH, Babola T, Pregernig G, So K, Nguyen M, Su M, Palermo A, Bergles DE, Burns JC, Müller U. Hair cell mechanotransduction regulates spontaneous activity andspiral ganglionsubtype specification in the auditory system. Cell. 2018;174(5):1247-63.e15.

40. Shrestha BR, Chia C, Wu L, Kujawa SG, Liberman MC, Goodrich LV. Sensory neuron diversity in the inner ear is shaped by activity. Cell. 2018;174(5):1229-46.e17.

41. Liu H, Pecka JL, Zhang Q, Soukup GA, Beisel KW, He DZZ. Characterization of transcriptomes of cochlear inner and outer hair cells. J Neurosci. 2014;34(33):11085-95.

42. Li Y, Liu H, Giffen KP, Chen L, Beisel KW, He DZZ. Transcriptomes of cochlear inner and outer hair cells from adult mice. Sci Data. 2018;5:180199.

\section{Publisher's Note}

Springer Nature remains neutral with regard to jurisdictional claims in published maps and institutional affiliations.
Ready to submit your research? Choose BMC and benefit from:

- fast, convenient online submission

- thorough peer review by experienced researchers in your field

- rapid publication on acceptance

- support for research data, including large and complex data types

- gold Open Access which fosters wider collaboration and increased citations

- maximum visibility for your research: over $100 \mathrm{M}$ website views per year

At BMC, research is always in progress.

Learn more biomedcentral.com/submissions 